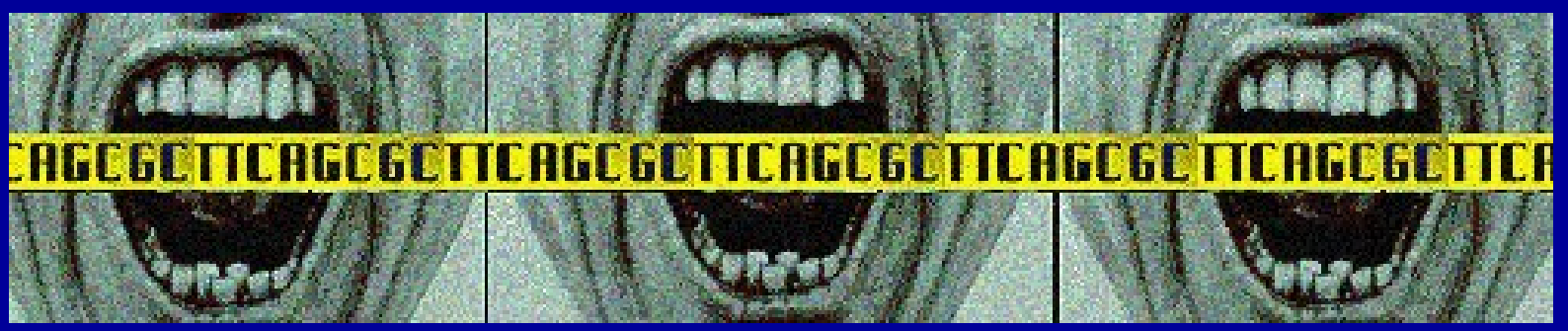

\title{
Recent Use of Behavioral Genetics in Criminal Cases
}

Nita Farahany, M.A., J.D.

Vanderbilt University Law School 


\section{Focus: Adjudication \& Sentencing}

Entry into the

System

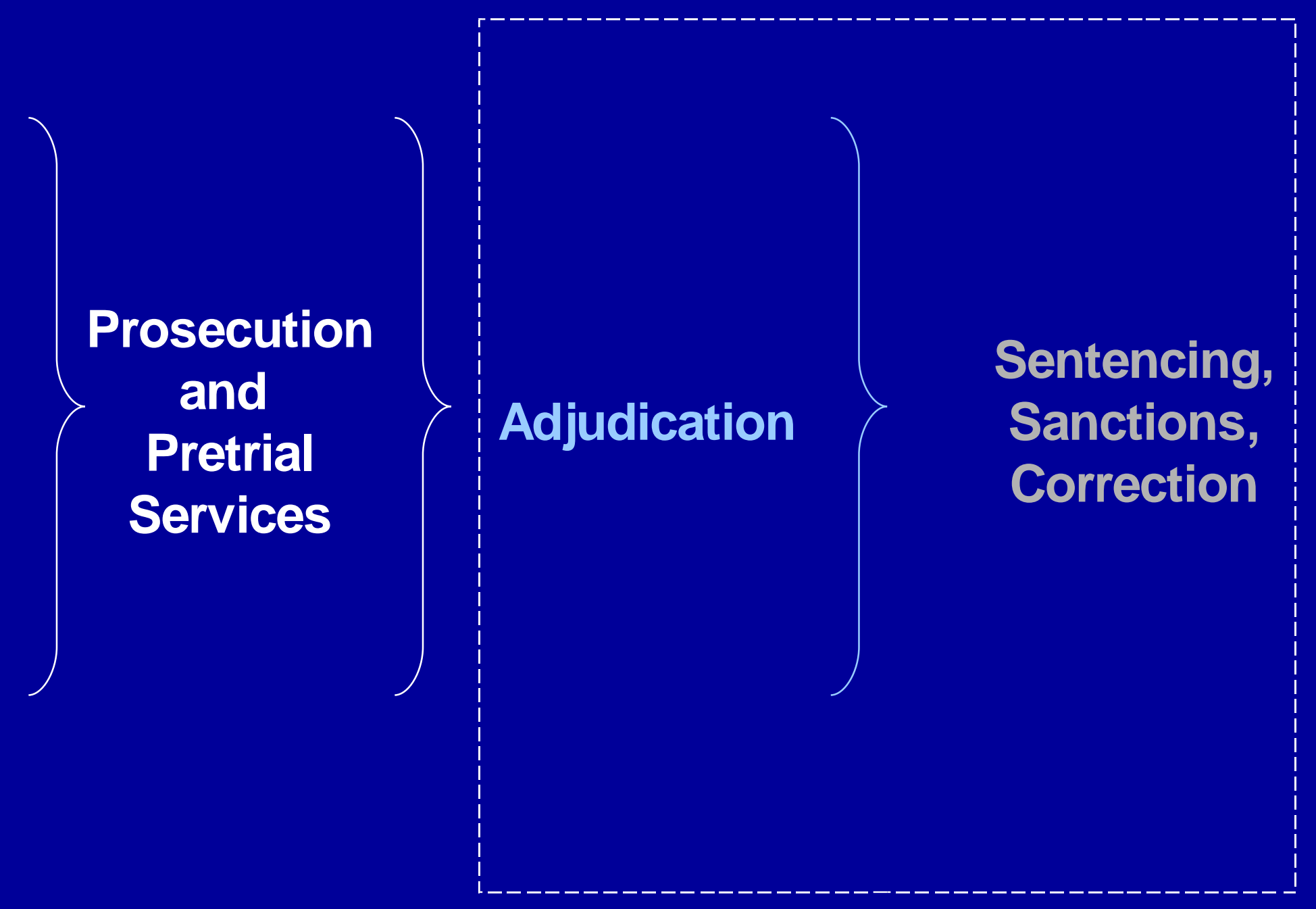




\section{Adjudication}

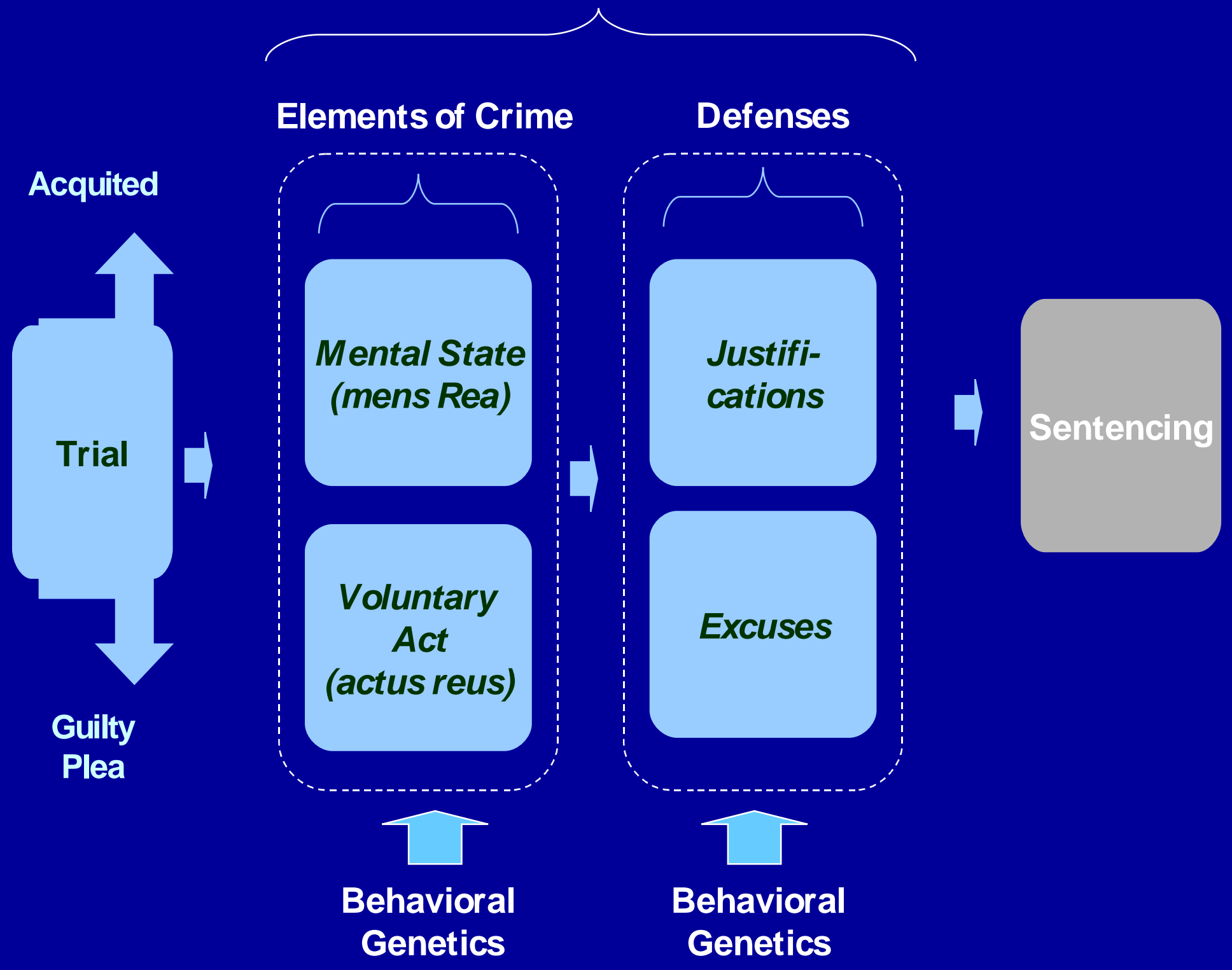




\section{Voluntary Act}

- A handful of criminal defendants have claimed their criminal act arose from a genetic predisposition to addiction, violence, impulsivity, or other behavioral traits, much like a reflex or convulsion, rather than a determination of their will

- The majority of courts to have wrestled with the defense that " because of overpowering compulsion," the defendant should be excused from criminal liability, have rejected it 


\section{Voluntary Act: Addiction}

- The majority of defendants claiming genetic involuntariness claim to have acted under the control of a drug or alcohol addiction arising from a genetic predisposition

- E.g., In United States v. Boushack, 1995 Wisc. App. LEXIS 378 (Wisc. Ct. App. 1995), the defendant argued that his intoxication was involuntary because it arose from his genetically based mental illness, and should have been a defense to his first-degree sexual assault conviction

- The court rejected his claim based on insufficient evidence establishing a genetic link to his chronic alcoholism 


\section{Voluntary Act: Lack of Control}

- Defendants introduce behavioral genetics to argue that they lacked control over their actions

- E.g., in Von Dohlen v. State, 602 S.E.2d 738 (S.C. 2004), cert. denied, 125 S.C.t 1645 (2005), the defendant claimed his criminal conduct, homicide and robbery of a pawn shop employee, was a product of his severe depression arising from his " genetic predisposition" and therefore involuntary

- A psychologist testified on appeal that as a result of " his altered mental state ' [the murder]' was not a volitional thing but out of his conscious awareness or control"

- Supreme Court of S.C. reversed and remanded finding the defendant' $s$ trial counsel did not adequately investigate his mental condition, and the trial outcome may have been different 


\section{Mental State}

- Several defendants have introduced genetic predisposition evidence to depression or intermittent explosive disorder to negate or diminish the mens rea element of the crime

- More recently, genotyping for MAOA and SLC6A4

- E.g., in State v. Davis, 2001 Tenn. Crim. App. LEXIS 341 (Tenn. Crim. App. 2001), Jacob Lee Davis, charged with shooting and killing a fellow classmate, argued that his mental defect, arising from his genetic predisposition, prevented him from forming the requisite intent to commit first-degree murder

- The jury rejected his claim and convicted him of first-degree murder 


\section{Mental State: Motive v. Intent}

- Many of these claims fail by addressing a defendant' $\mathrm{s}$ motivation to act, not intent to engage in the conduct

- E.g., in People v. Bobo, 3 Cal. Rptr. 2d 747 (Cal. Ct. App. 1990), Diane Rochelle Bobo claimed that she could not premeditate the stabbing and drowning of her three children and therefore should not have been found guilty of first-degree murder (three counts)

- A trial, experts testified that Bobo suffered from delusions and paranoid schizophrenia, onset by genetic factors, biochemical elements, and developmental experiences

- The California Court of Appeals rejected her claim, noting a distinction between objective intent to kill and subjective motivation to kill 


\section{Defenses: Excuses - Insanity}

- Some defendants have successfully introduced behavioral genetics evidence to bolster diagnosis of a mental disease or defect for the insanity defense

- When behavioral predisposition evidence is introduced to alone substantiate a mental disease or defect, it has been rejected as a matter of law

- E.g., in State v. Johnson, 549 N.E.2d 565 (Ohio Ct. App. 1989), the appellate court reversed a trial court decision allowing the defendant to plead insanity because his genetic predisposition, coupled with bad nutrition, caused him to react to stress in a compulsive, abnormal fashion

- The court concluded that the defendant' s condition did not satisfy the mental defect element for an insanity defense defense (unrecognized partial diminished capacity) 


\section{Sentencing}

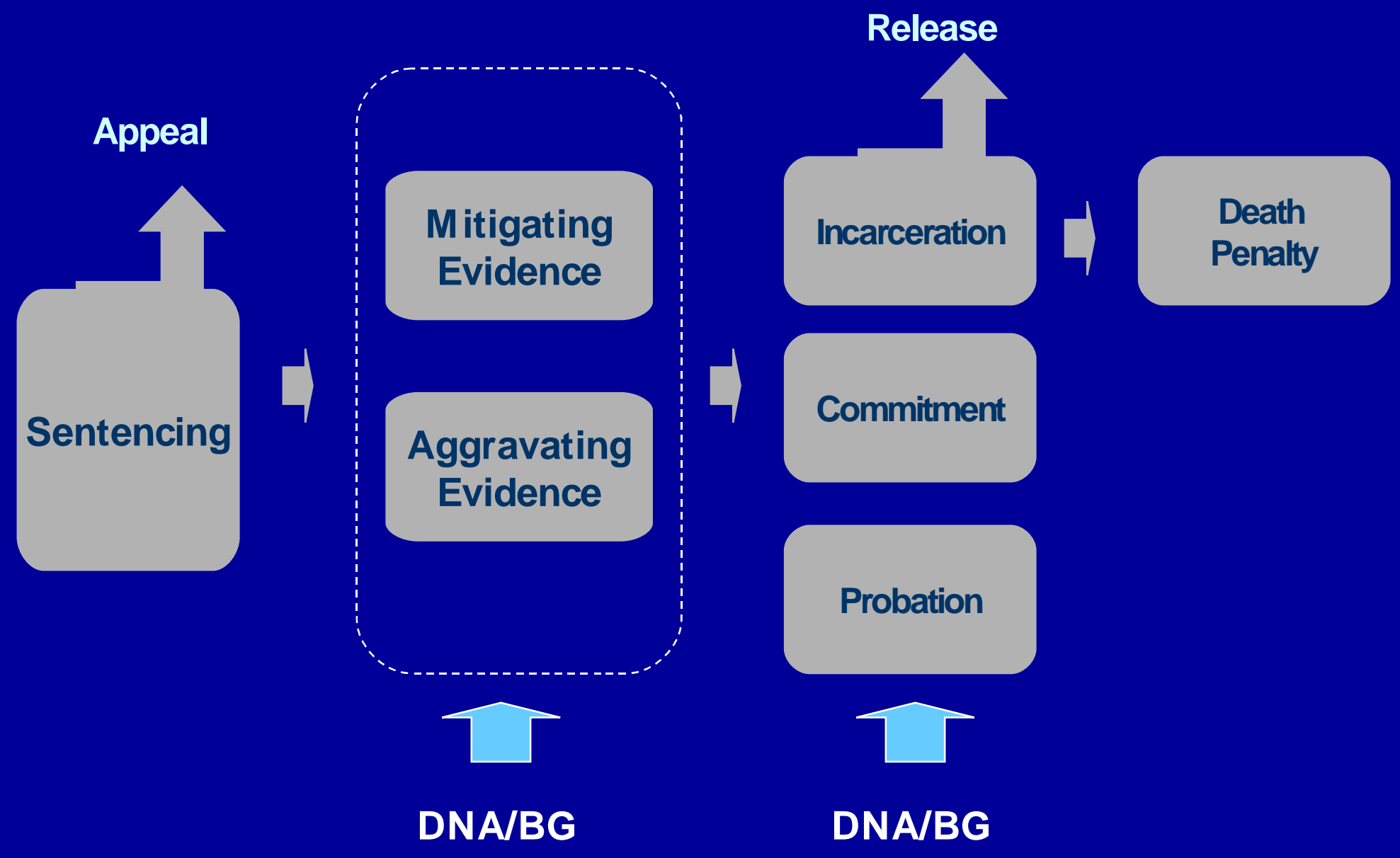




\section{Sentencing: Mitigation}

- The majority of defendants introduce behavioral genetics to mitigate their culpability and punishment

- Two forms: principal mitigation theory, one of several mitigating factors (along with other factors)

- Principal Mitigation theory

- E.g., in Hill v. Ozmint, 339 F.3d 187 (4th Cir. 2003), during the sentencing phase of the capital trial, Hill' s defense counsel argued his aggressive impulses arose from serotonin deficiency " attributable to genetics"

- After his arrest and incarceration, Hill began prescription medication that experts were to testify successfully curbed his aggressive impulses

- Theory of mitigation: " the death penalty was not warranted because Hill's aggressive behavior was genetic (i.e., beyond his control) and treatable," and he had in fact been treated and now a behaved as a different person 


\section{Sentencing: Aggravating}

- Behavioral genetics may be a double-edged sword for against some defendants during sentencing

- Used to denigrate the character of the defendant, justify longer sentencing, or to label the defendant as dangerous

- E.g., in Landrigan v. Stewart, 272 F.3d 1221 (9th Cir. 2001), Jeffrey Landrigan appealed his death sentence on the theory that his trial counsel was ineffective for failing to present mitigating evidence on his behalf

- Claimed should have introduced mitigating evidence to show his " biological background made him what he is"

- The Ninth Circuit initially rejected his claim, finding that a jury could equally find such evidence aggravating by viewing him as a " genetically programmed to be violent"

- Recently reheard en banc, and reversed and remanded, in part, for a new evidentiary hearing on sentencing 


\section{Conclusions}

- Behavioral genetics evidence has been introduced during criminal trials, with limited success

- Courts are divided on whether and when such evidence may be introduced

- Behavioral genetics may assist or cut against a defendant' $\mathrm{s}$ claims

- As the science becomes more specific, defendants are being

" genotyped" for specific gene variants

- Can be used either by defense or prosecution

- Further details are available in Nita Farahany \& James E.

Coleman, Jr., Genetics and Responsibility: To Know the Criminal From the Crime, 69 Law \& Contemporary Problems 115 (Winter/Spring 2006) 